\title{
POTENTIAL DEVELOPMENT AND COMIC PROXIMITY THROUGH THE VIDEO TUTORIAL FOR EXTRACULAR STUDENTS OF SMAN 3 BOYOLALI
}

\author{
Aan Ardian', Edi Kurniadi' ${ }^{2}$, Adam Wahida ${ }^{3}$ \\ 1,2,3 Post Graduate Program of Arts Education, Universitas Sebelas Maret, Indonesia \\ Email: ngoresanpermai@yahoo.com
}

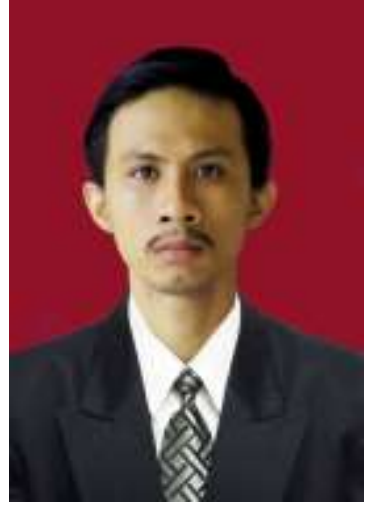

AAN ARDIAN

Keywords:

Video Tutorial,

Comics Creating,

Arts Extracurricular

\section{A B S T R A C T}

The role of video tutorial learning media is increasingly having an essential role in education, particularly the practice of learning Fine Arts in order to facilitate the learning process. Learning Fine Arts requires advance video tutorial media so that students can develop their potential and be motivated in learning, particularly in practical material. Through video tutorials as a guide to creating comics in learning, it is expected that it will become a guide for creating effective and efficient comics. The results showed that the video tutorial-based learning media developed were applicable for use in the learning process supported by student opinions with a percentage of $85.4 \%$ of students being able to create comics according to the rules and in a shorter time relatively. 


\section{International Journal of \\ Advanced Multidisciplinary Scientific Research (IJAMSR) ISSN:2581-4281}

\section{Introduction}

The extracurricular art class at SMA 3 Boyolali is an extracurricular for students to develop artistic potential, enthusiasm for the class is classified as active and the material provided is classified as attentive so that researchers are interested in exploring it. The interesting thing is that apart from the openness of the material, there are some extracurricular student works in which in the poster or illustration work there are word balloons in the poster material, even extracurricular students have participated in poster competitions and have won poster competitions at several campus events. This was supported by the first questionnaire that was given to students to retrieve data on student interest in comic material.

Based on the questionnaire, it can be assume that how the students are interested and have the potential to create comics, on the other hand they do not identify how the process of creating comics is according to the rules. The researchers analyzed the potential of extracurricular students that are able to receive comic material and want to develop new comic material and ideal video media with the hope that comic material in the extracurricular is more maximal, the researchers rests on the theory according to Iswidayati (2009: 13) the main function of learning media is as a tool teaching aids to create and influence the climate, conditions, and learning environment.

On the other hand, the conditions and facilities in the classroom, students can access smartphones and be connected to a wifi network, also encourages researchers to make a video product that can be accessed easily by students without being limited by space and time.

\section{Methods And Materials:}

The research is research and development. The subjects in the study were 11 students of the fine arts extracurricular activities of SMA N 3 Boyolali. The research data were obtained through questionnaires and tests. The data analysis technique was carried out using quantitative descriptive analysis techniques, by analyzing quantitative data obtained from questionnaires and field tests.

$$
\bar{X}=\frac{\sum X}{n}
$$

$X=$ mean of indicator

$\Sigma \mathrm{X}=$ Total score of indicator

$\mathrm{n}=$ total of indicator 
Vol 3, Issue 10, 2020 Imfact Factor:2.58 DOI: https://doi.org/10.31426/ijamsr.2020.3.10.3813

J A M S R

\section{International Journal of \\ Advanced Multidisciplinary Scientific Research (IJAMSR) ISSN:2581-4281}

\begin{tabular}{|c|c|}
\hline Category & Score \\
\hline VL (Very Less) & 1 \\
\hline L (Less) & 2 \\
\hline F (Fair) & 3 \\
\hline G (Good) & 4 \\
\hline VG (Very Good) & 5 \\
\hline
\end{tabular}

(Suharsimi Arikunto, 1993: 125).

\section{Results and Discussion}

The process of observing learning in the fine arts extracurricular class before and after using video tutorial media there was an improvement in student learning behavior. Students tended to be enthusiastic and focus on joining the learning process using comic tutorial video media as a guide. It can be identified based on the students' activities when learning using video tutorial media where students felt confused about the material that had been made and did not enjoy the process of creating comics, after using video media students tended to enjoy more and even be able to finish in a short time. This is in line with the extracurricular vision and mission. Vision and Mission are one of the complementary elements that must be present in an organization. Rohinah M. Noor (2012: 75) reveals that extracurricular has an extracurricular vision, which is the development of optimal potential, talents and interests, as well as the growth of independence and happiness of students that are useful for themselves, their families and society.

In the process before using video tutorial media, students tended not to focus on the process of working on comics because students had limited knowledge and technical questions about creating comics, even at the next meeting some students did not take extracurricular learning

After analyzing the data from the questionnaire before using the instructional videos, the percentage was $89.5 \%$, meaning that the students did not succeed in creating comics. Furthermore, the researcher went to the next stage by providing solutions to work comics with video tutorial learning media that were based on a percentage of data before using the media.

The description and data above indicate that if you do not use video tutorial guides in learning art, particularly practice, it is not ideal. According to Susilana and Riyana (2009: 147) the tutorial model is learning through computers where students are conditioned to follow a learning path that has been 
programmed with the presentation of material and exercises. The opinion above can be concluded that video tutorials are learning media that convey messages to students in the form of audio and visuals in interactive learning material so that students can learn independently which is not limited by space.

The learning process using video tutorial media obtained data gained from the results of trials on students then converted into a scale of 5 . Based on the results of data analysis, with 7 indicators filled in by 11 students where the results of the criteria were "very good" with a percentage of $85.4 \%$, so that overall video tutorial-based learning media are stated to be effective and students can complete comic works according to the rules faster than without video tutorial media that can be accessed anywhere without limited space and time. The author rests on the theory put forward by Rumampuk (1988: 6) states that learning media is any tool, both hardware and software that is used as a communication medium and whose purpose is to increase the effectiveness of the teaching-learning process.

Observations in learning are carried out to find out how students respond as objects in learning comic tutorial video media in fine arts extracurricular classes. The observation process was carried out twice before and after using the instructional animation video media. Based on the observations made before using the instructional animation video media, the learning process was less conducive where students felt not confident to create on comics, students became confused about creating stories and in the end the class was not conducive and even many students did not join extracurricular art classes. After using animated video media, students were enthusiastic in learning, students focused on learning media and work on comics more quickly in completing their work, even when the class was closed for school needs, students continued to work comics in front of the class run smoothly and completely.

In testing the effectiveness of the comic instructional video tutorial media product in the extracurricular activity of SMA Negeri 3 Boyolali, it was carried out in two ways, they were through the practice of creating comics before the use of comic tutorial video media and after using the video tutorial media there were 11 students. After calculating with a questionnaire to students, the results obtained were $85.4 \%$ after giving a questionnaire after using the video tutorial media, in terms of effectiveness with indicators at the point of 
making learning easier, competing competence, increasing attention, these indicators became the basis for determining that video-based learning media comic tutorials are said to be effective. This is in line with the opinion of Heinich, Molenda, and Russel (1982) in (Prayitno, 1989: 118) which states that learning media in teaching can concretize ideas or ideas that are conceptual in nature, thereby reducing student misunderstanding in learning and providing experiences significantly stimulate their own activities to learn, so that students are moved to do learning activities. With this student activity will increase motivation in students to learn, which in turn can affect student learning outcomes. The results of this study are also in accordance with what was stated by psychologist Jemore Burner in (Prayitno, 1989: 119) that if students can be given direct experience in learning (through media, demonstrations, field trips, dramatization), the learning situation will increase their excitement. and the student's interest in learning.

Based on the data and description, it is concluded that comic video tutorial media is effective in the learning process since after using the media students are more focused and this media becomes effective in the extracurricular learning process of fine arts at SMA Negeri 3 Boyolali. This is in line with the statement from Sugiyono (2010: 415) that the indicator of the effectiveness of the new teaching method is the speed of student understanding in lessons is higher, students are more creative, and learning outcomes improved. It is also strengthened by the theory according to Arsyad (2011: 26) which states that learning media can clarify the presentation of messages and information so that it can facilitate and improve learning processes and outcomes.

\section{Conclusion}

The objective of extracurricular activities is also achieved with this activity which focuses on enriching student competencies and developing potential or developing talents and interests of students in personal coaching efforts towards positive whole human development.

From the students, the percentage was $95.1 \%$. This means that the comic learning video tutorial video media is in the proper category. Students are interested and can understand the material conveyed through the media of comic learning tutorial videos and creating comics in accordance with comic principles. This was 
Vol 3, Issue 10, 2020 Imfact Factor:2.58 DOI: https://doi.org/10.31426/ijamsr.2020.3.10.3813

achieved with a percentage of $82.5 \%$ from material experts and from media experts testing video tutorial products, a percentage of $92.5 \%$ was obtained. It means that the material expert stated that the material in the comic learning video tutorial was in the proper category.
Animated learning video media based on comic tutorial videos was successfully developed as a learning media guide for extracurricular students at SMA N 3 Boyolali to enrich artistic competence by creating comics that are not limited by space and time using easily accessible video media.

Tables and Illustrations

Table 1. First Questionnaire that was Given to Students to Retrieve Data on Student Interest in Comic Material

\begin{tabular}{|c|c|c|c|c|c|c|}
\hline No & Question & 1 & 2 & 3 & 4 & 5 \\
\hline 1. & $\begin{array}{l}\text { Based on the art material } \\
\text { that has been presented, } \\
\text { are you interested in } \\
\text { comic material }\end{array}$ & 0 & 0 & 1 & 6 & 4 \\
\hline 2. & Have you read a comic? & 0 & 0 & 1 & 3 & 7 \\
\hline 3. & $\begin{array}{l}\text { Does comic have familiar } \\
\text { words related to our daily } \\
\text { life? }\end{array}$ & 0 & 0 & 1 & 3 & 7 \\
\hline 4. & $\begin{array}{l}\text { Have you not created } \\
\text { comic yet? }\end{array}$ & 0 & 0 & 3 & 4 & 4 \\
\hline 5. & $\begin{array}{l}\text { Are the knowledge and } \\
\text { technique being the } \\
\text { obstacle of creating } \\
\text { comic? }\end{array}$ & 0 & 0 & 0 & 6 & 5 \\
\hline
\end{tabular}

$\begin{array}{lccc}\text { Frequency } & 6 & 22 & 27 \\ \text { Socre } & 18 & 88 & 135\end{array}$

Total of Score $\quad 241$

Percentage $=\quad 87.6 \%$ 
Vol 3, Issue 10, 2020 Imfact Factor:2.58 DOI: https://doi.org/10.31426/ijamsr.2020.3.10.3813

I J A M S R

Table 2. Before Using Video Tutorial Comics

\begin{tabular}{|c|l|l|l|l|l|l|}
\hline No & \multicolumn{1}{|c|}{ Questions } & $\mathbf{1}$ & $\mathbf{2}$ & $\mathbf{4}$ & $\mathbf{5}$ \\
\hline $\mathbf{1 .}$ & $\begin{array}{l}\text { Is Determining the story line an } \\
\text { obstacle to creating comics? }\end{array}$ & & 1 & 5 & 5 \\
\hline $\mathbf{2 .}$ & $\begin{array}{l}\text { Less understanding and comic- } \\
\text { making techniques are an obstacle }\end{array}$ & & & & 2 & 9 \\
\hline $\mathbf{3 .}$ & $\begin{array}{l}\text { Is there no learning media such as } \\
\text { video tutorials is an obstacle? }\end{array}$ & & & 2 & 4 & 5 \\
\hline $\mathbf{4 .}$ & $\begin{array}{l}\text { Is 90 minutes of lessons an } \\
\text { obstacle? }\end{array}$ & & & 3 & 5 & 3 \\
\hline $\mathbf{5 .}$ & $\begin{array}{l}\text { Are you not confident enough to } \\
\text { express yourself creating comics }\end{array}$ & & 3 & 6 & 2 \\
\hline
\end{tabular}

$\begin{array}{llll}\text { Frequency } & 9 & 22 & 24 \\ \text { Score } & 27 & 88 & 120 \\ \text { Total of score } & 235 & & \\ \text { Percentage } & 85.4 \% & & \end{array}$


Vol 3, Issue 10, 2020 Imfact Factor:2.58 DOI: https://doi.org/10.31426/ijamsr.2020.3.10.3813

I J A M S R

\section{International Journal of}

Advanced Multidisciplinary Scientific Research (IJAMSR) ISSN:2581-4281

\section{Table 3. After Using Video Tutorial Comics}

\begin{tabular}{|c|c|c|c|c|c|c|}
\hline No. & Questions & 1 & 2 & 3 & 4 & 5 \\
\hline 1 & $\begin{array}{l}\text { Determining the time line can be } \\
\text { made easier through video tutorials }\end{array}$ & & & & 5 & 6 \\
\hline 2 & $\begin{array}{l}\text { Comic-creating techniques and } \\
\text { understanding are easier to } \\
\text { understand using video tutorial media }\end{array}$ & & & & 8 & 3 \\
\hline 3 & $\begin{array}{l}\text { With the video comic tutorial media, } \\
\text { it is easy to determine the type of } \\
\text { comic that being created }\end{array}$ & & & & 5 & 6 \\
\hline 4 & $\begin{array}{l}90 \text { minutes of extracurricular lesson } \\
\text { becomes enough to create comics } \\
\text { with video tutorial media }\end{array}$ & & & & 2 & 9 \\
\hline 5 & $\begin{array}{l}\text { By creating comics through video } \\
\text { tutorial media, it would be confident } \\
\text { in expressing comic-creating }\end{array}$ & & & 1 & 9 & 1 \\
\hline 6 & $\begin{array}{l}\text { With video tutorial media, it can be } \\
\text { used as a guideline for creating } \\
\text { comics at home }\end{array}$ & & & 2 & 4 & 5 \\
\hline 7 & $\begin{array}{l}\text { Video tutorials can assist speed up } \\
\text { comic creation }\end{array}$ & & & & 2 & 9 \\
\hline
\end{tabular}

Frequency

Score

Total of score

Percentage

\section{References}

1) Arsyad, Ashar. (2011). Media

Pembelajaran. Jakarta:Raja Grafindo

Persada.

2) Iswidayati, Sri.(2009). Pemanfaatan Media Pembelajaran Seni Budaya. Semarang: Lembaga Pengembangan Pendidikan dan Profesi UNES

3) Noor, Rohinah. (2012). The Hidden Curriculum Membangun Karakter Melalui Kegiatan Ekstrakurikuler. Yogyakarta: Insan Madani
4) Rumampuk, Dientje Borman. 1988. Media Instruksional IPS. Departemen Pendidikan dan Kebudayaan Direktorat Jenderal Pendidikan Tinggi Jakarta

5) Suharsimi Arikunto. (2008). Penelitian Tindakan Kelas. Jakarta: Bumi Aksara..

6) Susilana, Rudi dan Riyana, Cepi. (2009). Media Pembelajaran. Bandung: $\quad C V$ Wacana Prima. 